eISSN: 2655-8688

http://jurnal.stikes-sitihajar.ac.id/index.php/jhsp

hal: 160-166
pISSN: 2548-3943

Received Maret, Accepted Mei, Publish Juli

Copyright @2020. This is an open-access arcle distributed under the terms of the CreaveCommons Aribuon-NonCommercial-ShareAlike 4.0 Internaonal License () hp://creavecommons.org/licenses/by-

nc-sa/4.0/which permits unrestricted non-commercial used. distribuon and rebroducon in anv medium

\title{
Potensi Seledri (Apium Graveolens L) Sebagai Antihipertensi
}

\author{
Nada Naqiyya ${ }^{1^{*}}$ \\ ${ }^{1}$ Fakultas Kedokteran, Universitas Lampung \\ Email: nadanaqiyya0306@gmail.com
}

\begin{abstract}
ABSTRAK
Hipertensi merupakan masalah kesehatan dunia dan penyebab utama kematian dini di dunia. Prevalensi hipertensi di Indonesia terus meningkat dan pada tahun 2018 mencapai $34,1 \%$. Hipertensi merupakan penyakit kardiovaskular yang ditandai dengan peningkatan tekanan darah sistolik $\geq 140 \mathrm{mmHg}$ dan tekanan darah diastolik $\geq 90 \mathrm{mmHg}$. Hipertensi tidak mempunyai gejala khusus namun apabila terlambat dalam penanganannya dan tidak memperhatikan faktor risiko dapat menyebabkan komplikasi dan kematian organ target. Penatalaksanaan dalam hipertensi dapat dilakukan dengan pengobatan tradisional. Seledri merupakan tumbuhan yang dapat digunakan dalam pengobatan herbal hipertensi. Senyawa yang terkandung dalam seledri bersifat anti hipertensi seperti menurunkan kontraksi pembuluh darah dan menurunkan volume cairan ekstraseluler.
\end{abstract}

Kata kunci: Hipertensi, Seledri, Antihipertensi

\section{ABSTRACT}

Hypertension is a global health problem and a leading cause of premature death in the world. The prevalence of hypertension in Indonesia continues to increase and in 2018 it reaches $34.1 \%$. Hypertension is a cardiovascular disease characterized by an increasing systolic blood pressure $\geq 140 \mathrm{mmHg}$ and diastolic blood pressure $\geq 90 \mathrm{mmHg}$. Hypertension has no specific symptoms, but if it is too late in its handling and does not pay attention to risk factors, it can cause complications and target organ death. Management in hypertension can be done with traditional medicine. Celery is a plant that can be used in herbs treatmen of hypertension.. The compounds contained in celery are anti-hypertensive, such as reducing blood vessel contraction and decreasing the volume of extracellular fluid.

Keywords: Hypertension, Celery, Antihypertension 


\section{PENDAHULUAN}

Hipertensi merupakan salah satu penyebab utama kematian dini di dunia dan tercatat 10,4 juta kematian disebabkan oleh hipertensi. Diperkirakan 1,13 miliar orang di seluruh dunia menderita hipertensi dan sebagian besar berasal dari negara berkembang (WHO, 2019). Di Indonesia prevalensi hipertensi terus meningkat dari $25,8 \%$ pada tahun 2013 menjadi 34,1\% pada tahun 2018 (Kementrian Kesehatan, 2019). Diperkirakan 15 juta orang menderita hipertensi namun hanya $4 \%$ yang merupakan hipertensi terkontrol dan 50\% diantaranya tidak mengetahui sebagai penderita hipertensi sehingga tidak menghindari faktor risiko dan cenderung menjadi hipertensi berat (Oktadoni \& Fitria, 2016).

Hipertensi adalah kondisi dimana tekanan darah sistolik $\geq 140 \mathrm{mmHg}$ dan tekanan darah diastolik $\geq 90 \mathrm{mmHg}$ setelah pemeriksaan berulang baik di klinik maupun di rumah (Thomas Unger et al., 2020). Secara umum hipertensi merupakan penyakit tanpa gejala, namun apabila sudah progresif akan mengakibatkan keadaan serius seperti kompikasi ginjal, jantung, mata dan organ vital lainnya (Kurniawan \& Sulaiman, 2019). Namun apabila terdapat gejala biasanya hampir sama dengan penyakit lainnya, seperti sakit kepala, sepat lelah, penglihatan kabur, telinga berdenging, rasa berat di tengkuk dan lainnya(Setiati, Alwi, Sudoyo, \& Simadibrata, 2017).

Penatalaksanaan pada penderita hipertensi pada umumnya bertujuan untuk menurunkan tingkat morbiditas, mortalitas akibat hipertensi dan menjaga tekanan darah sesuai dengan target (Yulanda \& Lisiswati, 2016). Penderita tekanan darah tinggi pada umunya akan mendapatkan obat untuk menstabilkan tekanan darah. Namun pemakaian obat modern dalam jangka waktu panjang akan menimbulkan efek yang tidak baik bagi tubuh, sehingga dibutuhkan alternative lain diantaranya adalah penggunaan obat tradisional. Penggunaan obat tradisional dinilai lebih aman karna relative lebih kecil efek samping yang dihasilkannya dan tidak membutuhkan terlalu banyak biaya (Alamsyah, Nurhidayat, \& Rosjidi, 2017).

Salah satu tumbuhan yang sering digunakan dalam pengobatan tradisional atau herbal adalah seledri (Apium Graveolens L). Seledri mempunyai banyak khasiat salah satunya adalah sebagai antihipertensi (Syahidah \& Sulistyaningsih, 2018). Beberapa senyawa yang terkandung dalam seledri memiliki kemampuan dalam menurunkan tekanan darah, salah satunya adalah Apigenin yang mempunyai sifat sebagai vasodilator yang berhubungan dengan efek hipotensifnya (Oktadoni \& Fitria, 2016).

\section{PEMBAHASAN \\ Hipertensi}

Hipertensi merupakan keadaan dimana tekanan darah seseorang mengalami peningkatan presisten diatas atau sama dengan 140/90 $\mathrm{mmHg}$. Presisten merupakan istilah yang digunakan terhadap tekanan darah yang meningkat baik diukur di klinik, maupun di luar klinik, termasuk rumah dan juga selama melakukan aktivitas harian (Setiati et al., 2017).

Penyebab hipertensi digolongkan menjadi dua golongan besar, yaitu hipertensi primer dan hipertensi sekunder. Hipertensi primer merupakan penyumbang $90 \%$ kasus hipertensi yang penyebabnya tidak dapat diketahui dan $10 \%$ nya merupakan hipertensi sekunder yang terjadi apabila terdapat gangguan aliran darah pada ginjal atau tumor pada medulla adrenal (Lauralee, 2014).

Faktor utama penyebab hipertensi belum dapat diketahui, namun terdapat beberapa faktor yang dapat meningkatkan risiko seseorang untuk menderita hipertensi, diantaranya umur, jenis kelamin dan genetic yang merupakan faktor risiko yang tidak dapat diubah serta faktor lingkungan yang terdiri dari pola makan, obesitas, stress, 
olahraga, merokok, konsumsi alcohol dan dislipedemia yang merupakan faktor risiko yang dapat diubah (Setiati et al., 2017).

Hipertensi merupakan manifestasi gangguan keseimbangan hemodinamik system kardiovaskular yang mana penyebabnya adalah multi faktor, sehingga tidak bisa diterangkan dengan hanya satu mekanisme tunggal (Nuraini, 2015). Salah satu contohnya adalah interaksi antara pola makan dengan usia. Berdasarkan penelitian yang dilakukan oleh Kurniawan \& Sulaiman (2019), diketahui pola makan berhubungan dengan tingkat hipertensi pada lansia. Proses penuaan pada lansia akan menyebabkan hilangnya kemampuan jaringan secara perlahan untuk memperbaiki diri dan mempertahankan fungsi normalnya. Sehingga pada umumnya lansia tidak dapat bertahan terhadap kerusakan dan infeksi yang dideritanya. Hal ini akan berdampak terhadap system tubuh salah satunya adalah kardiovaskular (Sulaiman \& Anggraini, 2017). Pola makan yang mengandung banyak garam pada lansia akan menyebabkan asupan $\mathrm{NaCl}$ meningkat menyebabkan ginjal harus bekerja lebih keras untuk mengekresi garam keluar tubuh. Apabila upaya ginjal melebihi ambang batas, maka ginjal akan meretensi h20 sehingga volume intravascular meningkat dan menyebabkan curah jantung juga meningkat sehingga terjadi peningkatan tekanan darah. jika keadaan ini terjadi terus menerus maka akan menyebabkan baroreseptor beradaptasi dan mempertahankan pada tingkat tekanan yang lebih tinggi sehingga terjadi hipertensi yang presisten (Lauralee, 2014; Siregar, SZ, \& Ginting, 2014).

Mekanisme hipertensi disebabkan oleh empat faktor, yaitu volume intravaskuler, aktivasi saraf simpatis, sistem renin angiotensin aldosteron (RAA) dan dinding vascular pembuluh darah (Setiati et al., 2017).

Beberapa faktor risiko seperti stress, genetic, dan merokok akan mengaktivasi saraf simpatis menyebabkan pengeluaran neurotransmitter (nor epinefrin-NE) yang meningkatkan permebelitas ca2+ membrane. Selanjutnya kontraktilitas jantung akan meningkat lalu diikuti dengan peningkatan tekanan darah dan terjadi agregasi platelet. Hal tersebut dapat memicu terjadinya kerusakan miokard. Apabila hal ini terjadi, akan terjadi penurunan kontraktilitas yang menyebabkan penurunan tekanan darah (Saputra, Rahayu, \& IS, 2013).

Bila tekanan darah menurun, terjadi penurunan vaskularisasi pada ginjal yang membuat ginjal akan melepaskan renin. Renin akan mengubah angiotensinogen yang dibuat di hati menjadi angiotensin I, lalu angiotensin I akan diubah menjadi angiotensin II oleh enzim ACE (angiotensin coverting enzyme). Angiotensin II ini menyebabkan dua aksi (Nuraini, 2015)

Aksi pertama ialah meningkatkan sekresi hormone ADH (antidiuretik). ADH berfungsi untuk mengatur volume dan osmolaritas urin. Apabila terjadi peningkatan $\mathrm{ADH}$, volume urin yang dikeluarkan dari tubuh akan berkurang sehingga meningkatkan kepekatan dan osmolaritas urin. Kompensasi yang dilakukan dengan menarik cairan intraseluler untuk meningkatkan volume cairan ektraseluler. Akibatnya volume darah meningkat dan menyebabkan kenaikan tekanan darah (Nuraini, 2015).

Aksi kedua ialah menstimulasi sekresi hormon aldosteron. Hormone ini akan mengakibatkan retensi $\mathrm{H} 2 \mathrm{O}$ dan $\mathrm{Na}$ dari tubulus ginjal. Peningkatan konsentrasi $\mathrm{Na}$ akan dikompensasi dengan meningkatkan volume cairan ektraseluler yang pada akhirnya akan meningkatkan tekanan dan volume darah (Nuraini, 2015)

Cairan intravaskuler merupakan bagian dari cairan ekstraseluler yang berada di system vaskular. Volume cairan intravascular memiliki peranan penting terhadap kestabilan tekanan darah. apabila volume cairan intravaskuler meningkat maka akan menyebabkan peningkatan curah jantung dan TPR (Total Peripheral resistance) vasokontriksi. Akibatnya terjadi ekspansi volume intravaskuler sehingga tekanan darah 
meningkat (Chloe Park et al., 2018).

Dinding pembuluh darah akan mengalami kerusakan apabila terjadi peningkatan tekanan darah terus menerus disertai dengan faktor risiko yang tidak dapat dikelola. Vascular biologi akan berubah menjadi semakin tebal akibat lesi vascular, thrombosis, vasokontriksi, inflamasi dan rupture (Setiati et al., 2017). Disfungsi endotel akan meningkatkan permebealitas vascular yang memungkinkan komponen lipoprotein untuk menembus dan mengendap pada subendotel. Peningkatan konsentrasi angiotensin II merangsang pertumbuhan sel otot polos, meningkatkan peradangan dan akhirnya mempercepat oksidasi LDL (Kopaei, 2014). Hal tersebut dapat memicu terjadinya aterosklerosis apabila tidak segera ditangani dan dapat berlanjut ke penyakit kardiovaskular.

\section{Seledri}

Seledri merupakan salah satu tanaman yang mudah ditemukan di Indonesia karena iklimnya yang cocok untuk pertumbuhan seledri (Syahidah \& Sulistyaningsih, 2018). Seledri akan berkembang dengan baik di tempat yang kelembapannya tinggi namun bersuhu rendah (Sowbhagya, 2014). Berdasarkan taksonomi seledri termasuk dalam divisi Spermatophyta, subdivisi Angiospermae, kelas Dicotyledone, bangsa Apiales, suku Apiaceae, Apium dan jenis A. graveolens L (ITIS, 2020). Berdasarkan bentuknya seledri terbagi menjadi 3 macam, yaitu seledri potong, seledri umbi dan seledri daun. Seledri daun merupakan tanaman yang paling banyak ditemukan di Indonesia. Tinggi seledri dapat mencapai $60-90 \mathrm{~cm}$. Batangnya bergerigi dan bercabang. Daun seledri bebentuk bulat telur dengan pinggir bergerigi dan terdiri atas tiga lobus. Daun seledri berwarna hijau tua licin. Bunga seledri berukuran kecil dan berwarna abuabu-abu putih yang hanya ada dari bulan juli sampai November (Arisandi \& Sukohar, 2016).

Seledri lebih banyak digunakan oleh masyarakat Indonesia sebagai sayuran, campuran dalam makanan dan juga penyedap rasa (Adawiyah \& Afa, 2018). Namun sebagian masyarakat juga menggunakan seledri sebagai tanaman obat (Dewi, Walanda, \& Sabang, 2016). Berdasarkan hasil analisis secara farmakologis hampir semua bagian dari seledri bermanfaat sebagai obat. Akar seledri berkhasiat sebagai diuretik dan skomakik. Biji dan buahnya berkhasiat sebagai antispasmodik, menurunkan kadar asam urat darah, antirematik. Seledri juga berkhasiat sebagai penenang (sedatif), peluruh kentut (karminatif), pereda nyeri (antiinflamasi), antioksidan, antibakteri, anti kanker dan juga antihipertensi (Dewi et al., 2016; Dwinanda, Afriani, \& Hardisman, 2019; Syahidah \& Sulistyaningsih, 2018)

\section{Kandungan Kimia Seledri dan Potensi Sebagai Antihipertensi}

Dari berbagi penelitian diketahui seledri mempunyai berbagai kandungan senyawa yang bermanfaat untuk kesehatan dan cukup potensial untuk dikembangkan sebagai obat salah satunya adalah anti hipertensi. Seledri mengandung fenol dan furanokumarin. Fenol (155.41-177.23mg/100g) terdiri atas graveobiosid A and B, flavanoid (apiin, apigenin), isokuersitrin, tanin (3.89-4.39 $\mathrm{mg} / 100 \mathrm{~g}$ ) dan asam fitat $(19.85-22.05 \mathrm{mg} / \mathrm{g})$. furanokumarin terdiri atas selerin, bergapten, apiumosid, apiumetin, apigravrin, osthenol, isopimpinelin, isoimperatorin, celereosid, dan 5, 8-hydroxy methoxypsoralen. Pada hasil analisis fitokimia, diketahui ekstrak methanol biji seledri mengandung karbohidrat, flavonoid, alkaloid, steroid dan glikosida (Al-Snafi, 2014). Seledri mengandung minyak esensial dengan hasil senyawa yang telah diisolasi antara lain $d$-limonene, $d$-selinene, sedanolide, terpineol, santalol, selinene, nerolidol, $d$ carvone, $\beta$-pinene, $\beta$-myrcene (Al-Asmari \& Kadasah, 2014). Daun seledri juga 
mengandung vitamin $\mathrm{A}, \mathrm{K}, \mathrm{C}$, magnesium, kalium, riboflavin, kalsium, zat besi, fosfor, tiamin dan nikotinamid (Oktadoni \& Fitria, 2016; Syahidah \& Sulistyaningsih, 2018).

Apigenin yang merupakan flavonoid alami memiliki pengaruh terhadap kontrakilitas otot polos pembuluh darah (Vasodilator) (Je, Kim, \& La, 2014) . mekanisme kontraksi terjadi apabila terdapat peningkatan $\mathrm{Ca}$ pada sel, menyebabkan $\mathrm{Ca}$ sitosol meningkat dan memicu kontraksi pembuluh darah sehingga meningkatkan tekanan darah. Jika terjadi pada sel otot jantung maka akan memperkuat kontraksi otot jantung sehingga jantung memompa lebih keras dan terjadi peningkatan tekanan darah (Anggraini, Rusdi, \& Ibrahim, 2016). Apigenin dalam daun seledri akan memblokade Ca sehingga tidak dapat menyatu dengan sel otot polos pada pembuluh darah dan jantung sehingga tidak terjadi kontraksi. Pembuluh darah akan melebar sehingga darah mengalir dengan lancar dan tekanan darah menurun (Oktadoni \& Fitria, 2016).

Vitamin $\mathrm{C}$ dapat menurunkan tekanan darah sekitar $5 \mathrm{mmHg}$, melalui perannya memperbaiki kerusakan arteri karena hipertensi. Vitamin $\mathrm{C}$ membantu menjaga tekanan darah normal dengan cara mencegah penumpukan kolesterol pada dinding pembuluh darah. Vitamin $\mathrm{C}$ akan meningkatkan laju kolesterol dibuang dan meningkatkan kadar HDL sehingga akan memulihkan elastisitas pembuluh darah(Arie, Munyamah, \& Trimawati, 2016; Oktadoni \& Fitria, 2016).

Kalium pada seledri diketahui dapat menurunkan volume cairan ektstra seluler dengan menarik cairan ekstraseluler masuk ke dalam cairan intraseluler, sehingga terjadi perubahan keseimbangan pompa natrium-kalium yang akan menyebabkan penurunan tekanan darah. Salah satu strategi dalam penanganan hipertensi adalah mengubah keseimbangan $\mathrm{Na}+$ (Oktadoni \& Fitria, 2016).

Seledri mengandung fitosterol yang merupakan komponen fitokimia yang berguna untuk melawan kolesterol. Fitosterol dalam seledri berfungsi mencegah aterosklerosis, komplikasi akibat disfungsi endotel oleh hipertensi (Dwinanda et al., 2019). Magnesium dan zat besi pada seledri dapat membersihkan sisa metabolism dan simpanan lemak yang berlebih dalam pembuluh darah. sehingga mencegah kekakuan pada pembuluh darah darah sehingga tidak terjadi retensi vaskuler (Oktadoni \& Fitria, 2016).

Selain itu, seledri mengandung 3-n-butyl phthalide $(3 \mathrm{nB})$, suatu senyawa yang tidak hanya bertanggung jawab untuk bau yang khas seledri, tetapi juga telah ditemukan untuk menurunkan tekanan darah dengan merelaksasi atau melemaskan otot-otot halus pembuluh darah (Oktadoni \& Fitria, 2016). Pemberian masing-masing $300 \mathrm{mg} / \mathrm{kg}$ ekstrak etanol, methanol dan heksana biji seledri dapat menurunkan tekanan darah sebesar 23, 24, dan $38 \mathrm{mmHg}$ dan menaikkan denyut jantung sebesar 27, 25 dan 60 denyut per menit. Hasil analisis dengan high performance liquid chromatography (HPLC) menunjukkan bahwa kandungan senyawa n-butylphtalide (NBP) pada ekstrak heksana seledri 3.7-4 kali lebih besar dibandingkan pada ekstrak metanol dan etanol. Senyawa NBP pada seledri menjadi konstituen hidrofobik yang aktif sebagai antihipertensi (Moghadam, Hassanpour, Imenshahidi, \& Mohajeri, 2013).

\section{KESIMPULAN}

Berdasarkan pembahasan diatas, maka diketahui kandungan dalam seledri (Apium graveolens $L$ ) berpotensi sebagai agen antihipertensi. Oleh karenanya diperlukan penelitian lebih lanjut apabila seledri akan dikembangkan menjadi obat untuk hipertensi. 


\section{REFERENSI}

Adawiyah, R., \& Afa, M. (2018). Pertumbuhan Tanaman Seledri (Apium Graveolens L.) Pada Berbagai Media Tanam Tanpa Tanah Dengan Aplikasi Pupuk Organik Cair (POC). Biowallacea, 5(1), 750-760.

Al-Asmari, A., \& Kadasah, S. (2014). An Updated Phytopharmacological Review on Medicinal Plant of Arab Region: Apium graveolens Linn. International Journal for Pharmaceutical Research Scholars, 3(1), 671-677.

Al-Snafi, A. (2014). The Pharmacology of Apium graveolens. - A Review. International Journal for Pharmaceutical Research Scholars, 3(1), 671-677.

Alamsyah, A., Nurhidayat, S., \& Rosjidi, C. (2017). Studi Komparasi Daun Seledri (Apium Graveolens Linn) Dalam Bentuk Jus Dan Air Rebusan Terhadap Penurunan Tekanan Darah Pada Penderita Hipertensi. Journal Health Science, 1(1), 31-45.

Anggraini, P., Rusdi, R., \& Ibrahim, E. (2016). Kadar Na+, K+, Cl-, Dan Kalsium Total Serum Darah Serta Hubungannya Dengan Tekanan Darah Pada Penderita Hipertensi. Bioma, 12(1), 50-66.

Arie, N., Munyamah, U., \& Trimawati, T. (2016). Pengaruh Pemberian Air Rebusan Seledri Pada Lansia Penderita Hipertensi Di Dusun Gogodalem Barat. Jurnal Keperawatan Komunitas, 2(1), 46-51.

Arisandi, R., \& Sukohar, A. (2016). Seledri (Apium graveolens L) sebagai Agen Kemopreventif bagi Kanker. Jurnal Majority, 5(2), 95-100.

Chloe Park, Fraser, A., D, L., Jones, S., Smith, G. D., Lawlor, D. A., \& Chaturvedi, N. (2018). Elevated Blood Pressure in Adolescence Is Attributable to a Combination of Elevated Cardiac Output and Total Peripheral Resistance Evidence Against Hyperkinetic State. AHA Journal, 71, 1103-1108. https://doi.org/10.1161/HYPERTENSIONAHA.118.11925

Dewi, E., Walanda, D., \& Sabang, S. (2016). Pengaruh Ekstrak Seledri (Apium Graveolens L.) Terhadap Kelarutan Kalsium Dalam Batu Ginjal. Jurnal Akad. Kimia, 5(3), 127132.

Dwinanda, A., Afriani, N. H., \& Hardisman. (2019). Pengaruh Jus Seledri (Apium graveolens L.) terhadap Gambaran Mikroskopis Hepar Tikus (Rattus norvegicus) yang Diinduksi Diet Hiperkolesterol. Jurnal Kesehatan Andalas, 8(1), 68-75.

ITIS. (n.d.). Apium graveolens var. dulce. Retrieved July 4, 2020, from https://www.itis.gov/servlet/SingleRpt/SingleRpt?search_topic=TSN\&search_value $=182185 \#$ null

Je, H. D., Kim, H. D., \& La, H. oh. (2014). The Inhibitory Effect of Apigenin on the Agonist-Induced Regulation of Vascular Contractility via Calcium DesensitizationRelated Pathways. Biomol Ther (Seoul), 22(2), 100-105.

Kementrian Kesehatan. (2019). Buku Pedoman Manajemen Penyakit Tidak Menular. Jakarta: Kementrian Kesehatan Republik Indonesia.

Kopaei, M. (2014). Atherosclerosis: Process, Indicators, Risk Factors and New Hopes. International Journal Of Preventive Medicine, 5(8), 927-946.

Kurniawan, I., \& Sulaiman. (2019). Hubungan Olahraga, Stress Dan Pola Makan Dengan Tingkat Hipertensi Di Posyandu Lansia Di Kelurahan Sudirejo I Kecamatan Medan Kota. JHSP, 1(1), 10-17.

Lauralee, S. (2014). Fisiologi Manusia Dari Sel Ke Sistem (8th ed.). Jakarta: EGC.

Moghadam, Hassanpour, M., Imenshahidi, M., \& Mohajeri. (2013). Antihypertensive Effect of Celery Seed on Rat Blood Pressure in Chronic Administration. Journal of Medicinal Food, 16(6), 558-563.

Nuraini, B. (2015). Risk factors Of Hypertension. Jurnal Majority, 4(5), 10-19. 
Oktadoni, S., \& Fitria, T. (2016). Khasiat Daun Seledri Terhadap Tekanan Darah Tinggi Pada Pasien Hiperkolesterolmia. Jurnal Majority, 5(2), 120-125.

Saputra, B., Rahayu, \& IS, I. (2013). Profil Penderita Hipertensi Di RSUD Jombang Periode Januari-Desember 2011. Jurnal Saintika Medika, 9(2), 116-120.

Setiati, S., Alwi, I., Sudoyo, A. w, \& Simadibrata, M. (Eds.). (2017). Buku Ajar Ilmu Penyakit Dalam (6th ed.). Jakarta: Interna Publishing.

Siregar, A., SZ, Y., \& Ginting, S. (2014). Faktor-Faktor Penyebab Terjadinya Hipertensi Pada Lansia Di Upt Pelayanan Sosial Lanjut Usia Anak Dan Balita Binjai Dan Medan Tahun 2014. Jurnal Ilmiah Pannimed, 9(2), 129-133.

Sowbhagya, H. (2014). Chemistry, Technology, and Nutraceutical Functions of Celery (Apium Graveolens L.): An Overview. Critical Reviews in Food Science and Nutrition, 54(3), 389-398.

Sulaiman, \& Anggraini. (2017). Sosialisasi Pencegahan Kasus Stroke Pada Lanjut Usia Di Desa Hamparan Perak Kecamatan. Jurnal Pengabdian Kepada Masyarakat, 1(2), 70-74.

Syahidah, F., \& Sulistyaningsih, R. (2018). Potensi Seledri (Apium Graveolens) Untuk Pengobatan: Review Article. Jurnal Farmaka Suplemen, 16(1), 55-62.

Thomas Unger, Borghi, C., Charchar, F., Khan, N. A., Poulter, N. R., Prabhakaran, D., ... Schlaich, M. (2020). International Society of Hypertension Global Hypertension Practice Guidelines. AHA Journal, 75, 1334-1357. https://doi.org/10.1161/HYPERTENSIONAHA.120.15026

WHO. (2019). Hypertension. Retrieved from https://www.who.int/news-room/factsheets/detail/hypertension

Yulanda, G., \& Lisiswati, R. (2016). Penatalaksanaan Hipertensi Primer. Jurnal Majority, $6(1), 21-33$. 